\title{
Effect of tomatine on termites Odontotermes wallonensis (Wasmann) vis-a-vis antifeedant and repellent activity
}

\section{R. NISHA* AND D.S. RAJAVEL ${ }^{1}$}

Department of Crop Protection, Imayam Institute of Agriculture and Technology, Kannanur, Thuraiyur, TRICHY (T.N.) INDIA

${ }^{1}$ Department of Agricultural Entomology, Agricultural College and Research Institute, Killikulam, TUTICORIN (T.N.) INDIA

\section{ARITCLE INFO}

Received : 30.12 .2015

Revised : 11.02 .2016

Accepted : 25.02.2016

\section{KEY WORDS :}

Tomatine, Secondary alkaloid, Termites, Azadirachtin, Repellent activity
*Corresponding author:

Email: nisharengadoss@gmail.com

\begin{abstract}
A secondary alkaloid, tomatine was extracted from unripen fruits and leaves of tomato. It is a potent antifungal and insecticidal compound that interacts with sterols in the membranes of the insects and shows efficacy against insects and many species of termites. In this research, investigations were carried out to study the antifeedant and repellent activity of tomatine against the termite species Odontotermes wallonensis Wasmann. The result concluded that lowest consumption of food by $O$. wallonensis workers was recorded in Azadirachtin $100 \mathrm{ppm}(0.15 \mathrm{~g})$ followed by Tomatine $250 \mathrm{ppm}$ $(0.60 \mathrm{~g})$. Soldiers and nymphs of O.wallonensis consumed $0.54 \mathrm{~g}$ and $0.56 \mathrm{~g}$ food in tomatine $250 \mathrm{ppm}$ treatment whereas in treated check (Azadirachtin $100 \mathrm{ppm}$ ) consumed $0.14 \mathrm{~g}$ in both castes as compared to untreated check (1.33 and $1.46 \mathrm{~g})$. And also exhibited the highest repellent activity towards termites at all the doses. Tomatine $1000 \mathrm{ppm}$ caused 82.13, 73.41 and 88.67 per cent repellent activity whereas Azadirachtin $100 \mathrm{ppm}$ caused $88.67,78.96$ and 92.00 per cent in $O$. wallonensis workers, soldiers and nymphs, respectively.
\end{abstract}

How to view point the article : Nisha, R. and Rajavel, D.S. (2016). Effect of tomatine on termites Odontotermes wallonensis (Wasmann) vis-a-vis antifeedant and repellent activity. Internat. J. Plant Protec., 9(1): 97-101. 